\title{
ANALISIS POLA KERJASAMA ORANG TUA DAN GURU SEKOLAH DASAR DI ACEH BARAT SELAMA PANDEMI COVID-19
}

\author{
Aulia Monitasari ${ }^{1}$, Faizatul Husna ${ }^{2}$, Hanifuddin Jamin ${ }^{3}$ \\ ${ }^{1}$ Guru SD An Nahla Meulaboh Aceh Barat \\ ${ }^{2,3}$ Dosen STAIN Teungku Dirundeng Meulaboh \\ Email: auliamonitasari98@mail.com ${ }^{1}$, faizatulhusna@staindirundeng.ac.id ${ }^{2}$, \\ hanifstainmbo@gmail.com ${ }^{3}$
}

\begin{abstract}
Abstrak
Sekolah dan keluarga merupakan faktor penting untuk mendorong keberhasilan prestasi siswa, sehingga harus saling berkolaborasi. Akan tetapi pandemi Covid-19 yang terjadi membuat siswa dan guru beralih dari kelas tatap muka ke kelas virtual. Hal ini pula yang membuat perubahan pola kerjasama antara sekolah dan orang tua. Dengan menggunakan 6 tipe kerjasama oleh Epstein (1997), penelitian ini ingin menyelidiki pola kerjasama yang terjadi antara guru dan sekolah selama pandemi. Metode dalam penelitian ini adalah kualitatif dengan menggunakan teknik purposive sampling. Wawancara dilakukan terhadap kepala sekolah, guru dan orang tua siswa. Hasil penelitian menunjukkan bahwa terjadi perbedaan pola kerjasama sebelum pandemi dan ketika pandemi berlangsung, dimana ada sejumlah tipe kerjasama yang tidak terjadi ketika pandemi.

Kata kunci: keterlibatan orang tua, pola kerjasama, pandemi Covid-19, framework Epstein

Abstract

School and family are important factors for student achievement, so they must collaborate with each other. However, the Covid-19 pandemic that has occurred has made students and teachers switch from face-to-face classes to virtual classes. This also changes the pattern of collaboration between schools and parents. Using the 6 types of collaboration by Epstein (1997), this study aims to investigate the patterns of collaboration that occur between teachers and schools during a pandemic. The method in this research is qualitative using purposive sampling technique. Interviews were conducted on principals, teachers and parents of students. The results showed that there were differences in the pattern of cooperation before the pandemic and during the pandemic, where there were a number of types of cooperation that did not occur during the pandemic.
\end{abstract}

Keywords: parental involvement, cooperation patterns, Covid-19 pandemic, Epstein framework

\section{PENDAHULUAN}

Keterlibatan orang tua dalam pendidikan anak-anak mereka merupakan hal yang sangat penting karena tantangan yang dihadapi anak tidak dapat hanya diselesaikan oleh sekolah saja atau keluarga saja. Kenyataannya, penelitian telah menemukan bahwa cara tercepat untuk meningkatkan prestasi akademik siswa adalah dengan meningkatkan jumlah dan kualitas keterlibatan orang tua (Fuller \& Olsen, 1998). Guru dan orang tua memiliki tujuan yang sama dalam pendidikan anak: mendidik, membimbing, mendorong, dan 
memimpin anak-anak mereka menjadi individu yang mampu mencapai kebahagiaan di dunia dan akhirat.

Tentu saja diperlukan kerjasama yang baik antara guru dan orang tua untuk memenuhi tujuan tersebut. Demikian pula interaksi antara guru dan orang tua harus kooperatif. Jika tujuan ini tidak terpenuhi, maka akan berdampak buruk pada proses belajar mengajar, sehingga menurunkan kualitas pendidikan. Oleh karena itu perlu dilakukan tindakan-tindakan untuk mendukung terlaksananya peningkatan kegiatan belajar bagi anak oleh orang tua, pengajar, dan keduanya dalam hubungan kerjasama untuk saling membantu dalam mendorong kegiatan belajar siswa tersebut. Meskipun tantangannya tidak kecil, karena kerjasama orang tua dan guru sebagai pelaksana dan penanggung jawab akan tercapai dengan tujuan yang jelas.

Serangkaian interaksi dalam keluarga, sekolah, masyarakat, sekolah dengan orang tua, sekolah dengan masyarakat, dan masyarakat dengan orang tua semuanya berdampak pada perkembangan anak. Pertumbuhan individu dipengaruhi oleh setiap lapisan lingkungan yang selalu dinamis. Akibatnya, pertumbuhan anak terkait erat dengan interaksi sekolah-orang tua. Tingkat pencapaian belajar anak akan dipengaruhi oleh interaksi antara kedua belah pihak. Atas dasar ini dapat dikemukakan pentingnya keterlibatan orang tua dalam pendidikan anaknya sebagai pihak yang berinteraksi langsung. Hal ini akan berdampak pada tumbuh kembang anak. Oleh karena itu, sekolah harus mampu merangkul orang tua dalam mendidik siswa secara bersama-sama.

Terlebih saat pandemi covid-19 yang secara tak terduga membawa beberapa perubahan dan pengalaman belajar baru baik bagi guru maupun siswa. Siswa yang jarang belajar memanfaatkan teknologi dalam belajar, kini terpaksa menggunakan gadget untuk menerima pembelajaran. Orang tua juga kini dituntut untuk menjadi rujukan bagi anak ketika belajar. Sementara guru yang tidak pernah menganggap platform pembelajaran online sebagai media utama penyampaian pelajaran serta berinteraksi, dengan siswa, saat ini dipaksa untuk membiasakan diri menggunakan teknologi ini. Singkatnya, melalui pandemi ini, semua orang telah belajar banyak hal baru (Hidayati \& Husna, 2020).

\section{RUMUSAN MASALAH:}

Pertanyaan penelitian yang dibahas dalam penelitian ini adalah sebagai berikut:

1. Bagaimana pola kerja sama antara orang tua siswa dan guru selama pandemi?

2. Apa saja faktor-faktor penghambat dan pendukung kerja sama antara orang tua siswa dan guru selama pandemi?

\section{TINJAUAN PUSTAKA}

Anggota keluarga merupakan faktor utama yang berkontribusi terhadap perkembangan anak. Rumah adalah tempat anak bersosialisasi pertama sekali sekaligus menjadi madrasah pertama untuk memperoleh pendidikan. Karena itu, membentuk anak melalui pendidikan dirumah sangat penting sebelum anak masuk ke lembaga pendidikan formal. Pengaruh pendidikan keluarga pada anak-anak dapat bermanifestasi lewat tindakan baik secara langsung ataupun secara tidak langsung, yakni melalui iklim psikososial yang ada 
dalam keluarga. Sehingga, strategi orang tua dalam mendidik anak dalam keluarga harus dipersiapkan sebab akan menentukan perkembangan kepribadian dan prestasi pendidikan anak (Porumbu \& Necşoi, 2013).

Menurut Dohner-Chávez, (2006), "Selain dari latar belakang etnis atau ekonomi, keterlibatan orang tua dalam pendidikan anak memiliki efek mendalam pada keberhasilan akademis" (hal. 43). Kebutuhan akan pedoman, strategi, dan teknik yang memadai untuk melibatkan orang tua di sekolah sangat penting dan harus menjadi prioritas setiap administrator. Jika pendidik sekolah umum ingin orang tua memikul lebih banyak tanggung jawab, sekolah perlu mengambil pendekatan proaktif yang mengidentifikasi solusi untuk menghilangkan hambatan keterlibatan orang tua (Smith et al., 2008).

Jika merujuk pada sejarah keterlibatan orang tua, sejumlah peneliti (Bloom, 1992; Lopez,1992) menggambarkan perubahan pola keterlibatan orang tua dalam sekolah pada era 1980-an. Selama dekade ini, orang tua menjadi terpolarisasi dan menyekolahkan anaknya di sekolah umum serta terlibat secara aktif dalam pendidikan sang anak, seperti dalam reformasi sekolah. Sementara, orang tua lainnya memindahkan anak-anak mereka keluar dari sekolah umum dan memasukkan mereka ke sekolah-sekolah swasta, sekolah keagamaan atau sekolah kota yang memiliki tinggi homogenitas lebih tinggi. Selanjutnya, dalam decade ini, terjadi peniurunan tingkat kemitraan orang tua-guru karena adanya perubahan struktur yang dramatis di keluarga. Jumlah ibu bekerja, orang tua tunggal, dan keluarga tiri meningkat drastis. Sehingga sekolah memiliki tantangan lebih besar, sebab kesulitan mendorong keterlibatan orang tua yang berasal dari tingkat sosioekonomi yang rendah.

Akan tetapi menurut Becher (1984), anak akan mencapai prestasi yang baik jika benar-benar didukung oleh orang tua yang intens berinteraksi dengan mereka; terlepas dari status sosial ekonomi orang tua tersebut. Tipikal orang tua ini juga berkomunikasi dengan menggunakan kosakata yang luas dan memberikan bekal strategi pemecahan masalah bagi anak, serta membantu memperkuat konsep yang dipelajari anak-anak mereka di sekolah. Hal ini cukup beralasan sebab anak akan terus memilih orang tua sebagai sumber informasi, bahkan dalam bidang di mana orang tua tidak memiliki keahlian dalam bidang tersebut.

Dengan demikian, para pendidik setuju bahwa keterlibatan orang tua menjadi kunci keberhasilan perkembangan akademik siswa, meskipun definisi keterlibatan orang tua tersebut bisa saja ditafsirkan berbeda-beda. Definisi yang umum keterlibatan orang tua adalah partisipasi orang tua dalam kegiatan di sekolah dan di rumah, seperti menjadi sukarelawan di sekolah; berkomunikasi dengan guru; membantu pekerjaan rumah; dan menghadiri open house, serta rapat antara orang tua dan guru (Bower \& Griffin, 2011; Epstein et al., 2009). 
Sementara itu, Lopez, Scribner, dan Mahitivanichcha (2001) mendefinisikan keterlibatan orang tua sebagai dukungan terhadap prestasi akademik siswa atau partisipasi dalam kegiatan yang diprakarsai sekolah

Menurut Epstein (1995), ada beberapa tipe keterlibatan orang tua yang bisa dilakukan oleh pihak sekolah yaitu dalam bentuk parenting, komunikasi, volunteering, belajar di rumah, pengambilan keputusan, dan pelibatan orang tua dalam pelayanan masyarakat. Seperti yang katakan oleh Sanders and Epstein (1998):

The six types of involvement are: 1) parenting - helping all families establish home environments that support children as students; 2) communicating - designing and conducting effective forms of communication about school programs and children's progress; 3) volunteering - recruiting and organizing help and support for school functions and activities; 4) learning at home -providing information and ideas to families about how to help students at home with school work and related activities; 5) decision-making - including parents in school decisions, and 6) collaborating with the community - identifying and integrating resources and services from the community to strengthen and support schools, students, and their families.

Tipe yang pertama mengacu pada tanggung jawab keluarga untuk memastikan kesehatan dan keselamatan anak (misalnya, membesarkan dan mengawasi anak, penanaman kedisiplinan, dan bimbingan di setiap tingkat usia) dan penyediaan kondisi rumah yang mendukung pembelajaran dan perilaku. Tipe kedua mengacu pada komunikasi dengan sekolah tentang kemajuan akademik (misalnya pengumuman, pembagian rapor, rapat). Selanjutnya, tipe ketiga berkaitan dengan partisipasi orang tua dalam kegiatan di lingkungan sekolah misalnya, acara, lokakarya dan sebagainya. Tipe keempat berupa komunikasi dengan orang tua yang memantau, dan membantu pekerjaan rumah atau kegiatan belajar anak-anak mereka. Tipe kelima mengacu pada orang tua yang menerima peran pengambilan keputusan dalam komite yang memantau kemajuan sekolah (misalnya, Persatuan Guru Orang Tua, dewan penasihat, atau komite atau kelompok lain di sekolah). Tipe keenam yakni keterlibatan kerja sama sekolah dengan masyarakat, yang berkaitan dengan pegintegrasian berbagai lembaga masyarakat dan sumber daya yang mendukung program sekolah (misalnya komite sekolah) (Epstein, Coates, Salinas, Sanders, \& Simon, 1997). 
Tabel 1. Kerangka kerja Epstein

\begin{tabular}{|c|c|c|c|}
\hline Tipe & $\begin{array}{c}\text { Based } \\
\text { Involvemen } \\
t\end{array}$ & Deskripsi & Contoh \\
\hline 1. Parenting & Rumah & $\begin{array}{l}\text { Kewajiban dasar } \\
\text { keluarga }\end{array}$ & $\begin{array}{l}\text { Memenuhi kebutuhan siswa } \\
\text { seperti kesehatan dan lingkungan } \\
\text { rumah, membantu keluarga } \\
\text { dengan keterampilan mengasuh } \\
\text { anak, membangun disiplin dan } \\
\text { motivasi siswa, membayar uang } \\
\text { sekolah tepat waktu, } \\
\text { menyelesaikan kendala sebagai } \\
\text { orang tua. }\end{array}$ \\
\hline 2. Komunikasi & Sekolah & $\begin{array}{l}\text { Kewajiban Dasar } \\
\text { Sekolah }\end{array}$ & $\begin{array}{l}\text { Dikomunikasikan oleh sekolah } \\
\text { kepada orang tua melalui surat, } \\
\text { melalui telepon, atau pertemuan } \\
\text { guru-orang tua. }\end{array}$ \\
\hline 3. Volunteering & Sekolah & $\begin{array}{l}\text { Kontribusi } \\
\text { sekolah }\end{array}$ & $\begin{array}{l}\text { Menjadi sukarelawan di ruang } \\
\text { kelas untuk berbagi dan dukungan } \\
\text { dalam proses belajar atau } \\
\text { menghadiri acara-acara sekolah. }\end{array}$ \\
\hline $\begin{array}{l}\text { 4. Pembelajaran } \\
\text { di rumah }\end{array}$ & Rumah & $\begin{array}{l}\text { Keterlibatan dalam } \\
\text { kegiatan belajar di } \\
\text { rumah }\end{array}$ & $\begin{array}{l}\text { Membantu anak mengerjakan } \\
\text { pekerjaan rumah (PR) } \\
\text { dikategorikan ke dalam kontrol } \\
\text { belajar dan mendukung belajar. }\end{array}$ \\
\hline $\begin{array}{l}\text { 5. Pengambil } \\
\text { an } \\
\text { Keputusan }\end{array}$ & Sekolah & $\begin{array}{lr}\text { Partisipasi dalam } \\
\text { pengambilan } & \\
\text { keputusan, } & \text { tata } \\
\text { kelola, } & \text { dan } \\
\text { advokasi } & \end{array}$ & $\begin{array}{l}\text { Berdiskusi dalam perkumpulan } \\
\text { orang tua-guru, komite sekolah, } \\
\text { dan kunjungan rumah. }\end{array}$ \\
\hline $\begin{array}{l}\text { 6. Kolaboras } \\
\text { i dengan } \\
\text { masyaraka } \\
\mathrm{t}\end{array}$ & Sekolah & $\begin{array}{l}\text { Kolaborasi dan } \\
\text { pertukaran dengan } \\
\text { Organisasi } \\
\text { masyarakat }\end{array}$ & $\begin{array}{lcr}\text { Menjalin } & \text { hubungan } & \text { dengan } \\
\text { kelompok } & \text { lain dan } & \text { berbagi } \\
\text { tanggung } & \text { jawab } & \text { untuk } \\
\text { memperkuat } & \text { program } & \text { sekolah, } \\
\text { praktik } & \text { keluarga } & \text { dan } \\
\text { pengembangan siswa. } & \end{array}$ \\
\hline
\end{tabular}

Guru ingin orang tua aktif dalam pendidikan anak-anak mereka karena berbagai alasan. Keterlibatan orang tua di sekolah, menurut Greenberg dalam Padmonodewo (2003), akan membantu guru dalam meningkatkan rasa percaya diri anak, mengurangi masalah disiplin siswa, dan meningkatkan dorongan anakGuru yang memandang orang tua sebagai mitra kunci atau rekan kerja dalam pendidikan anak-anak mereka akan lebih menghargai dan menerima partisipasi orang tua. Hubungan kerjasama antara sekolah dan orang tua akan membantu tercapainya tujuan bersama, seperti saling membantu dan melengkapi; 
memberikan bantuan keuangan; mencegah perilaku negative anak; dan mengembangkan rencana yang baik untuk anak bersama-sama.

\section{METODE PENELITIAN}

Penelitian ini merupakan penelitian deskriptif dengan teknik kualitatif. Dengan menunjukkan apa yang sebenarnya terjadi, penelitian deskriptif kualitatif berusaha mengungkap peristiwa atau fakta, kondisi, atau fenomena yang terjadi sepanjang penyelidikan. Kita bisa mendapatkan pemahaman yang lebih besar tentang bagaimana individu menjelaskan pengalaman mereka, membangun dunia mereka, dan berhubungan dengan pengalaman mereka (Merriam, 2015). Penelitian ini melibatkan 12 informan yang terdiri atas orang tua dan guru yang ada di Aceh Barat dengan menggunakan teknik purposive sampling. Data diambil melalui wawancara mendalam mengenai pola kerjasama yang terjadi antara guru dan siswa di Aceh Barat.

\section{HASIL PENELITIAN}

\section{Pola Kerja Sama Antara Orang Tua Siswa dan Guru Selama Pandemi}

Dari hasil wawancara dengan orang tua dan guru, ada sejumlah tema utama yang muncul, diantaranya parenting dan komunikasi

\section{Parenting}

Sejak anak-anak dirumahkan, orang tua kemudian yang berperan menjadi guru bagi anak dirumah. Peran orang tua dalam tipe ini tidak hanya sebagai pengawas anak belajar, melainkan juga memastikan fasilitas anak belajar dirumah. Sebagaimana diungkapkan oleh AH, orang tua siswa di sebuah MIN 8 Aceh Barat, "Ini memang belajar dirumah. Tapi anakanak juga butuh hp (handphone-red). Kemudian laptop dan tempat dia belajar biar nyaman. Jadi saya sediakan kebutuhan itu." AH memiliki pekerjaan tetap di sebuah kampus di Aceh Barat, sehingga hambatan terutama yang berkaitan dengan latar sosial ekonomi bisa diatasi.

Akan tetapi, bagi AT seorang ibu rumah tangga yang memiliki suami yangberpfrofesi sebagai penarik becak, penyediaan fasilitas ini menjadi hal yang sulit baginya. "Ayahnya dia menurun pendapatan selama Covid, kemudian sekolah harus pakai hp. Anak saya tiga, jadi tidak mungkin saya penuhi semua. Mereka gantian, tapi jadi sering terlambat kumpul tugas," ujar AT.

2. Komunikasi

Dalam pendidikan, komunikasi lebih tepat digambarkan sebagai proses penyampaian pesan dari satu orang, yaitu pengajar (sumber pesan), kepada orang atau kelompok orang lain, 
yaitu orang tua atau murid (penerima pesan), atau sebaliknya. Komunikasi adalah metode pelaksanaan pendidikan berkesinambungan. Hal ini seperti di ungkapkan orang tua siswa yang berinisial ST, "Komunikasi sangat penting dalam pembelajaran antara pihak sekolah guru dan orang tua agar ada keseimbangan antara dirumah dan disekolah.”

Demikian pula, pihak madrasah dan orangtua berpandangan bahwa jika hanya satu pihak yang berperan dalam proses pendidikan anak maka aktivitas belajar yang diperoleh anak tidak akan optimal. Sebab, anak berada di madrasah lebih kurang 6 jam sehari dan menghabiskan waktu selebihnya bersama orangtuanya. Meskipun harus diakui madrasah memberikan pengaruh yang cukup signifikan pada perkembangan diri anak yaitu melalui proses belajar. Sehingga, pendidikan yang diterima anak di madrasah harusnya dilanjutkan oleh orangtua di rumah melalui bimbingan dan pendampingan bagi anak.

Hal ini seperti yang diungkapkan orangtua siswa berinisial J, "Kerja sama orang tua ini sangat penting, kita sebagai orang tua dengan adanya kerjasama dengan guru mudah tau gimana aktivitas-aktivitas yang terjadi sekolah, dan kita sebagai orang tua memeriksa apa yang telah dipelajari anaknya di madrasah. Jadi kita sebagai orang tua tau anaknya sudah sampai mana pengetahuannya.Terus di lanjutkanlah dirumah.Bukan cuek-cuek aja begitu. Jadi sangat berpengaruh kerja sama ini"

Pernyataan di atas, didukung oleh pernyataan kepala madrasah F, yang menyatakan: "Madrasah memang memberi pengaruh yang besar terhadap perkembangan anak, tapi perlu diketahui anak atau siswa sama kita dimadrasahkan hanya beberapa jam selebihnyakan dirumah sama mamak dan ayahnya."

Selanjutnya, komunikasi formal tetap dilakukan baik sebelum pandemi maupun ketika pandemi, yakni melalui surat menyurat, laporan hasil belajar (rapor), buku penghubung dan pertemuan dengan orang tua siswa. Dalam hal ini, rapor yang dibagi tiap semester menjembatani komunikasi antara guru dan orangtua seiring dengan informasi mengenai pencapaian siswa.

Sementara itu, komunikasi nonformal dilakukan melalui kunjungan rumah, telepon atau group whatsapp guru kelas dan siswa. Selama pandemi, kebanyakan guru dan orang tua di Aceh Barat saling berkomunikasi lewat whatsapp mengenai tugas dan materi pelajaran sekolah. Tak jarang, orang tua murid bertanya mengenai hal yang belum ia pahami melalui platform ini. Seperti diungkapkan oleh MZ, ayah dari siswa. "Kalau ada yang tidak paham, karena kan kita bukan guru, langsung saya WA gurunya. Langsung dibalas pas anak belajar.” 


\section{Pembelajaran di Rumah}

Sementara itu, di rumah orangtua berperan langsung dalam membantu anak mengejar ketertinggalannya selama pandemi berlangsung. Seperti hal yang di ungkapkan guru beinisial L: "Saya suka dalam hal orang tua membantu anak belajar dirumah karena dengan itu orang tua mengetahui pembelajaran dan pengetahuan anak disekolah." Hal tersebut dapat dilakukan dengan melanjutkan pembelajaran dirumah, mengulang materi pembelajaran, dan menerapkan apa-apa yang sudah dilakukan guru terhadap anak dimadrasah.Orang tua menemani anaknya belajar, bertanya tentang pengalamannya belajar dimadrasah dan lain sebagainya.

Hal senada juga diungkapkan orang tua berinial ZH. Ia menanggap keterlibatan orang tua belajar dirumah sangat penting untuk keberhasilan anak disekolah. "Saya kalau dirumah saya ulangi lagi hafalan anak saya, atau membantunya mengerjakan PR, kalau saya tidak tahu saya WA lagi gurunya. Dengan membantu anak belajar dirumah, kita tahu perkembangan anak kita disekolah."

\section{Faktor-faktor Penghambat Kerja Sama antara Orang Tua Siswa dan Sekolah Sebelum dan Selama Pandemi}

Ada seumlah faktor yang menghambat terjadinya kerjasama antara orang tua dan guru baik sebelum maupun ketika pandemi. Diantara faktor tersebut adalah perbedaan persepsi guru dan orang tua terhadap pola yang harus dibangun. Seorang guru mengungkapkan bahwa orangtua tidak bisa ikut campur dalam proses pembelajaran yang dilakukannya, seperti yang diungkapkan oleh guru berinisial KL: "Yang tau cara mengajarkan sesuatu itu kan kita ya sebagai guru."

Guru berpendapat bahwa mengajar adalah kewajiban mereka di madrasah, sedangkan orangtua memiliki kewajiban mendidik di rumah. Setelah diantar ke madrasah, maka anak menjadi tanggung jawab madrasah terutama guru. Sehingga segala sesuatu yang diajarkan disekolah, sepenuhnya ditetapkan oleh sekolah tanpa adanya masukan dari orang tua. Pandangan seperti ini dianggap sebagai salah satu faktor penghambat terjalinnya kerjasama guru dan orangtua terutama dalam meningkatkan aktivitas belajar siswa.

Sementara itu, ketika dalam situasi pandemi, para guru tidak bisa menjalin komunikasi yang intens dengan orang tua. Hal ini disebabkan karena kondisi yang mengharuskan para siswa tidak kesekolah sehingga pertemuan antara guru dan orang tua menjadi sulit. Ditambah lagi, pembelajaran dilakukan secara daring, sehingga komunikasi juga malah semakin sulit. Sementara, sejumlah orang tua berharap bahwa komunikasi bisa dilakukan dua arah antara 
guru dan orang tua. Sebagaimana diungkapkan oleh $\mathrm{ZH}$, "Dalam setahun pandemi guru-guru Cuma kasih tugas lewat WA.Kemudian suruh kerjakan. Kalau kita bertanya, baru dijelaskan. Tidak ada feedback. Kemudian tidak ada komunikasi dengan orang tua harus bagaimana kami ajarkan anak."

Selain itu, kendala yang dialami oleh guru adalah, salah satunya, mereka takut membangun komunikasi dengan orangtua karena dianggap terlalu mengatur pola asuh orangtua terlebih jika mereka bersikap tegas untuk melibatkan orangtua dalam pendidikan anak. "Kalau ke orang tua sulit kita jelaskan, karena akan memakan waktu, kemudian bidang ilmu juga beda. Kalau terlalu banyak kita atur, nanti kesannya jadi tidak enak.” Kendala selanjutnya yang dialami guru lain berinisial M, yakni, "Sebagian orang tua siswa kurang memperhatikan anaknya misalnya dalam mendidik orang tuanya itu acuh tak acuh terhadap aktivitas belajar anaknya, bahkan ada yang tidak memperhatikan tugas-tugas anaknya."

Sementara itu menurut pandangan orangtua, nasihat guru lebih didengar oleh anaknya, maka mereka tidak mau mencampuri urusan pendidikan anak disekolah. Selain itu orangtua menganggap bahwa guru lebih pintar dalam mendidik anak. Seperti yang diungkapkan orang tua siswa berinisial T, "Saya tidak terlalu bisa kasih pengetahuan tentang mendidik anak, makanya saya percaya sepenuhnya kepada guru. Lagian anak saya lebih dengarin kata gurunya dibandingkan kata saya".

Faktor lainnya adalah tuntutan pekerjaan orangtua. Orangtua siswa umunya datang ke madrasah anak hanya untuk keperluan untuk mengantar dan menjemput, ataupun jika ada undangan dari sekolah yang mengahruskan mereka hadir. Ssalah satu orangtua juga mengatakan, tidak akan datang kesekolah jika sang anak tidak mengalami masalah yang serius di madrasah. Ditambah lagi, kebanyakan orangtua memiliki pekerjaan yang mengharuskan mereka tidak meninggalkan pekerjaan tersebut sehingga mereka memiliki waktu terbatas untuk terlibat di sekolah, seperti yang diutarakan oleh orangtua siswa berinisial O: "Saya repot kalau harus meninggalkan jualan saya, karena cuma itu sumber penghasilan saya."

Sikap orangtua juga menjadi salah satu faktor yang menentukan tingkat kerjasama guru dan orangtua untuk meningkatkan aktivitas belajar siswa. Sikap tersebut biasanya ditunjukkan ketika pihak madrasah memberikan undangan kepada orang tua untuk datang, seperti yang dikatakan oleh guru RA: "Kadang memang orangtuanya yang tidak mau berkomunikasi dengan kita, katanya sih pokoknya saya ngikut aja" 


\section{PEMBAHASAN}

\section{Pola Kerja Sama antara Orang Tua Siswa dan Guru dalam Meningkatkan Aktivitas Belajar Siswa}

Pola kerjasama pertama yang dilakukan dalam menjalin kerjasama antara guru dan orangtua adalah melakukan komunikasi dengan orangtua. Jika merujuk pada enam tipe pola kerjasama yang ditawarkan Epstein, maka dalam penelitian ini hanya muncul 2 tipe saja. Sementara itu terdapat dua teknik komunikasi yang dapat dilterapkan untuk meningkatkan kerjasama guru dan orangtua, yaitu teknik komunikasi resmi atau formal dan teknik komunikasi tidak resmi atau non-formal. Di madrasah-madrasah di Aceh Barat, komunikasi formal dilakukan melalui perantara surat, ketika pembagianrapot dan saat rapat dengan wali murid. Sementara, komunikasi non-formal dilakukan melalui agenda kunjungan rumah, percakapan lewat telepon atau group Whatsapp atau pembicaraan ketika orangtua mengantar dan menjemput anaknya.

Pola kerjasama yang kedua adalah keterlibatan orangtua pada pembelajaran anak dirumah. Orang tua juga berperan sebagai guru dengan membimbing dan mendampingi anakanak di rumah mengejar materi yang tertinggal di kelas. Selain itu, orang tua melanjutkan pendidikan di rumah dengan menemani anak belajar dan mempraktekkan apa yang biasa dilakukan oleh pengajar madrasah di rumah.

Sementara itu, untuk tipe volunteering tidak terjadi saat pandemi, ini tidak lain karena pembatasa bagi kegiatan tatap muka. Sebelum pandemi, sejumlah orang tua terlibat aktif dalam kegiatan sekolah. Seperti diungkapkan oleh orang tua berinisial U, "Saya dilibatkan kalau ada acara, seperti acara maulid, mengisi ceramah. Sekarang kan sekolah daring, jadi kami tidak ikut lagi dalam kegiatan sekolah karena memang tidak ada acara.”

\section{Faktor-faktor Penghambat dan Pendukung Kerja Sama antara Orang Tua Siswa dan Guru Peningkatan Aktivitas Belajar Siswa}

Ada enam tipe bentuk kerjasama antara guru dan orangtua dalam meningkatkan aktivitas belajar siswa.Namun pada pada saat pandemi, tidak semuanya dapat berjalan lancar sesuai dengan harapan. Hal ini disebabkan oleh beberapa faktor.

Pada dasarnya, hambatan keterlibatan orang tua dapat dikategorikan ke dalam empat bidang, terutama berkaitan dengan kesulitan orang tua. Pertama, faktor keluarga, yang meliputi kepercayaan orang tua untuk terlibat dalam pendidikan anaknya; kehadiran orang tua di acara sekolah, konteks kehidupan orang tua, dan latar belakang orang tua, seperti kelas sosial, etnis, dan jenis kelamin. Kedua, faktor yang berkaitan dengan usia anak, hambatan 
belajar dan ketidakmampuan, penghargaan, dan bakat, serta masalah sikap. Selanjutnya, faktor hubungan orang tua-guru, terkait dengan penetapan tujuan dan jadwal, interaksi dengan orang lain dan penggunaan bahasa yang efektif. Terakhir, faktor lingkungan sosial yang berkaitan dengan masalah historis dan demografis, politik dan ekonomi.

Faktor yang peneliti temui di lapangan salah satunya adalah faktor hubungan orang tua- guru seperti perbedaan tujuan dan sudut pandang antara guru dan orang tua. Adalah pandangan guru terhadap orangtua siswa yang menganggap bahwa orangtua tidak perlu ikut campur dalam proses pembelajaran yang dilakukannya. Selain itu juga, guru mengalami beberapa kendala, Pertama kendala dalam membangun komunikasi dengan orangtua siswa. Guru merasa khawatir orangtua merasa digurui oleh mereka. Salah satu kekhawatiran tersebut disebabkan karena mereka lebih muda dibandingkan orangtua siswa. Sementara itu, sebagian orang tua siswa kurang memperhatikan anaknya misalnya dalam mendidik orang tuanya itu acuh tak acuh terhadap aktivitas belajar anaknya, bahkan ada yang tidak memperhatikan perlengkapan sekolah anaknya seperti alat tulis menulis, pakaian sekolah anaknya. Sehingga anaknya pergi sekolah dengan apa adanya. Padahal semua itu faktor yang dapat menghambat proses aktivitas belajar siswa.

Peneliti menghadapi faktor eksternal yaitu persepsi orang tua terhadap peran guru dalam proses pembelajaran. Mereka menegaskan bahwa anak-anak mereka lebih mengutamakan dan mengindahkan nasihat guru mereka daripada mereka, dan karena itu mereka enggan mengganggu pendidikan anak-anak mereka. Selain itu, mereka percaya bahwa guru lebih cerdas daripada mereka dalam hal mendidik anak-anak mereka. Pada saat yang sama, mereka kesulitan mendapatkan izin dari kantor untuk menghadiri undangan madrasah. Hambatan lain yang ditemukan oleh para peneliti adalah bahwa beberapa orang tua acuh tak acuh terhadap kemajuan pendidikan anak-anak mereka dan tidak mau mempelajarinya.

\section{KESIMPULAN}

Berdasarkan rumusan masalah, hasil penelitian menunjukkan bahwa terdapat perubahan pola kerjasama, dimana ada beberapa tipe framework yang tidak muncul. Penelitian ini didasarkan pada tipe keterlibatan orang tua menurut Epstein. Dapat ditarik kesimpulan bahwa orang tua memiliki persepsi yang berbeda terkait dengan keterlibatan mereka. Hal terpenting yang dipahami oleh orang tua adalah bahwa mereka memahami dengan baik tentang pengasuhan, tetapi mereka tidak benar-benar memiliki pengetahuan yang baik tentang jenis keterlibatan orang tua lainnya yang disebutkan dalam tipologi Epstein. 
Dengan demikian dalam penelitian ini pola yang muncul adalah tipe parenting, komunikasi dan keterlibatan orangtua pada pembelajaran anak dirumah. Sementara itu, faktor-faktor penghambat dan pendukung kerja sama antara orang tua siswa dan guru dalam meningkatkan aktivitas belajar siswa dipengaruhi oleh sejumlah faktor yaitu adalah perbedaan pandangan antara guru dan orangtua, tuntutan hidup dan sikap orangtua

Keterbatasan dalam penelitian ini adalah kurangnya eksplorasi tentang keterlibatan orang tua dalam wilayah yang lebih luas, sebab penelitian ini hanya terfokus di kabupaten Aceh Barat saja Oleh karena itu, perlu dilakukan penelitian lebih lanjut mengenai pola keterlibatan orang tua di kabupaten lainnya.

\section{DAFTAR PUSTAKA}

Becher, R. M. (1984). Parent involvement: A review of research and principles of successful practice.

Bloom, J. (1992). Parenting our school: A hand-on guide to education reform. Boston, MA: Little, Brown, and Company.

Bower, H. A., \& Griffin, D. (2011). Can the Epstein model of parental involvement work in a high-minority, high-poverty elementary school? A case study. Professional School Counseling, 15(2), 77-87. doi:10.5330/PSC.n.2011-15.77

Epstein, J. L., Coates, L., Salinas, K. C., Sanders, M. G., \& Simon, B. S. (1997). School, family, and community partnerships: Your handbook for action. Thousand Oaks, CA: Corwin.

Epstein, J. L., Sanders, M. G., Sheldon, S. Simon, B. S., Salinas, K. C., Jansorn, N. R.,... \& Williams, K. J. (2009). School, family, and community partnerships: Your handbook for action. Thousand Oaks, CA: Corwin.

Fuller, M. L., \& Olsen, G. W. (1998). Home-school relations: Working successfully with parents and families. Allyn \& Bacon.

Hidayati, T., \& Husna, F. (2020). Learning English from Home during the COVID-19: Investigating Learners' Experience for Online and Autonomous Learning. Langkawi: Journal of The Association for Arabic and English, 6(2), 202-217.

John W. Santrock. (2007). Perkembangan Anak. Jilid 1 Edisi 11. Jakarta: Erlangga,.

Lopez, R. (1992). Historical review of parental involvement in American schools. In A. L. Ensle, A. B. Bermudez, \& S. 1. Rakow, (Eds.), Critical issues in parental involvement. (pp. 53-56). Houston, TX: Research Center for Language and Culture, University of Houston-Clear Lake.

Lopez, G. R., Scribner, J. D., \& Mahitivanichcha, K. (2001). Redefining parental involvement: Lessons from high performing migrant-impacted schools. American Research Journal, 38(2), 253-288.

Merriam, S. B., \&Tisdell, E. J. (2015). Qualitative research: A guide to design and implementation. John Wiley \& Sons.

Patmonodewo, S. (2000). Pendidikan anak prasekolah. Rineka Cipta bekerjasama dengan Departemen Pendidikan \& Kebudayaan.

Porumbu, D., \& Necşoi, D. V. (2013). Relationship between parental involvement/attitude and children's school achievements. Procedia-Social and Behavioral Sciences, 76, 706-710. 
Sanders, M. G., \& Epstein, J. L. (1998). Sanders, M. G., \& Epstein, J. L. (1998). SchoolFamily-Community Partnerships in Middle and High Schools: From Theory to Practice. Report No. 22.

Wulandary, D., \& Herlisa, H. (2018). Parent Involvement in Schooling Processes: A Case Study in Aceh. Sukma: Jurnal Pendidikan, 2(1), 25-65. 